\title{
Preparation, Crystal Structure, Electronic Structure, Impedance Spectroscopy, and Raman Spectroscopy of $\mathrm{Li}_{3} \mathrm{SbS}_{3}$ and $\mathrm{Li}_{3} \mathrm{AsS}_{3}$
}

\author{
Sebastian Huber, ${ }^{[\mathrm{a}]}$ Christian Preitschaft, ${ }^{[\mathrm{a}]}$ Richard Weihrich, $^{[\mathrm{a}]}$ and Arno Pfitzner* ${ }^{*[\mathrm{a}]}$
}

Keywords: Thiometalate; Lithium; Crystal structure; Electronic structure; Ion conductor

\begin{abstract}
Li}_{3} \mathrm{SbS}_{3}$ was synthesized by solid-state reaction of stoichiometric amounts of $\mathrm{Li}_{2} \mathrm{~S}$ and $\mathrm{Sb}_{2} \mathrm{~S}_{3}$ in the ratio 3:1. The product is air and moisture sensitive. The crystal structure was determined from single crystals at room temperature. Pale grey $\mathrm{Li}_{3} \mathrm{SbS}_{3}$ crystallizes in the orthorhombic space group $P n a 2_{1}$ (no. 33) with $a=7.9671(5) \AA, b=$ 6.7883(5) $\AA, c=10.0912(8) \AA, V=545.76(7) \AA^{3}$, and $Z=4$ (data at $20{ }^{\circ} \mathrm{C}$ ). Antimony and sulfur atoms build isolated, trigonal pyramidal $\left[\mathrm{SbS}_{3}\right]^{3-}$ units, which are stacked along [100]. These $\left[\mathrm{SbS}_{3}\right]^{3-}$ units are connected by $\left[\mathrm{LiS}_{x}\right]$-polyhedra. The lithium ions have either a distorted tetrahedral coordination by sulfur in the case of $\mathrm{Li} 2$ and $\mathrm{Li} 3$ or a distorted square pyramidal environment in the case of Li1. The crystal structure is isotypic with $\mathrm{Li}_{3} \mathrm{AsS}_{3}$, which was obtained by reaction of
\end{abstract}

stoichiometric amounts of lithium, arsenic, and sulfur in the ratio $3: 1: 3$ in an excess of LiI. LiI serves only as a flux and is not incorporated in the crystal structure. $\mathrm{Li}_{3} \mathrm{AsS}_{3}$ crystallizes as colorless rods, space group Pna2 ${ }_{1}$ (no. 33) with $a=8.090(1) \AA, b=6.658(1) \AA, c=$ 9.868(1) $\AA, V=531.5(1) \AA^{3}$, and $Z=4$ (data at $20{ }^{\circ} \mathrm{C}$ ). Both compounds are confirmed as semiconductors with bandgaps close to $3 \mathrm{eV}$ from DFT-calculations with GGA and hybrid functionals. Impedance spectroscopic measurements of $\mathrm{Li}_{3} \mathrm{SbS}_{3}$ show a specific conductivity of $\sigma=1.6 \times 10^{-9} \Omega^{-1} \mathrm{~cm}^{-1}$ at $323 \mathrm{~K}$ and of $\sigma=5.4 \times 10^{-5} \Omega^{-1} \mathrm{~cm}^{-1}$ at $573 \mathrm{~K}$. The activation energy is $E_{A}=0.72 \mathrm{eV}$. Raman spectra of $\mathrm{Li}_{3} \mathrm{SbS}_{3}$ are dominated by the stretching modes of the $\left[\mathrm{SbS}_{3}\right]^{3-}$ units at 333,317 , and $301 \mathrm{~cm}^{-1}$ at room temperature.

\section{Introduction}

Chalcogenides and chalcogenometalates are an important class of solids. There is a huge variety of compounds with the general composition $M_{3}^{\mathrm{I}} P_{n} Q_{3}(M=\mathrm{Li}, \mathrm{Na}, \mathrm{K}, \mathrm{Rb}, \mathrm{Cs}, \mathrm{Cu}$, $\mathrm{Ag} ; P n=\mathrm{P}, \mathrm{As}, \mathrm{Sb}, \mathrm{Bi} ; Q=\mathrm{S}, \mathrm{Se}, \mathrm{Te}$ ) and some of them show a high ionic conductivity. Therefore, these materials become more and more important for the investigation of new solid electrolytes. Compounds like $\mathrm{Na}_{3} \mathrm{SbS}_{3},{ }^{[1]} \mathrm{K}_{3} \mathrm{SbS}_{3}$, ${ }^{[1]}$ $\mathrm{K}_{3} \mathrm{SbSe}_{3},{ }^{[2]} \quad \mathrm{Rb}_{3} \mathrm{SbSe}_{3},{ }^{[2]} \quad \mathrm{Cs}_{3} \mathrm{SbSe}_{3},{ }^{[2]} \quad \mathrm{Li}_{3} \mathrm{AsS}_{3},{ }^{[3,4]}$ $\mathrm{Na}_{3} \mathrm{AsS}_{3},{ }^{[1,5]} \mathrm{Na}_{3} \mathrm{AsSe}_{3},{ }^{[6]} \mathrm{K}_{3} \mathrm{AsS}_{3},{ }^{[1]} \mathrm{K}_{3} \mathrm{AsSe}_{3},{ }^{[6]} \mathrm{K}_{3} \mathrm{BiSe}_{3}$, $\mathrm{Rb}_{3} \mathrm{BiSe}_{3}$, and $\mathrm{Cs}_{3} \mathrm{BiSe}_{3}{ }^{[7,8]}$ have been synthesized and characterized. They all have isolated $\left[\mathrm{PnQ}_{3}\right]^{3-}$ units in common. In addition also modifications with a substitution of the alkali metal are well known. Similar compounds containing coinage metals instead of alkali metals are known, i.e., $\mathrm{Ag}_{3} \mathrm{AsS}_{3},{ }^{[9,10]}$ $\mathrm{Ag}_{3} \mathrm{AsSe}_{3},{ }^{[11-13]}$ and $\mathrm{Ag}_{3} \mathrm{SbS}_{3},{ }^{[9]}$ and $\mathrm{Cu}_{3} \mathrm{SbS}_{3},{ }^{[14-17]}$ and $\mathrm{Cu}_{3} \mathrm{SbSe}_{3} \cdot{ }^{[18]}$ Especially the copper containing thiometalates are currently discussed as thermoelectric materials. ${ }^{[19,20]}$ Isolated thioantimonate units are also observed in mixed chalcogenometalate halides like $(\mathrm{CuI})_{2} \mathrm{Cu}_{3} \mathrm{SbS}_{3},{ }^{[21,22]}(\mathrm{AgI})_{2}$ $\mathrm{Ag}_{3} \mathrm{SbS}_{3},{ }^{[23,24]}$ and $(\mathrm{LiI})_{2} \mathrm{Li}_{3} \mathrm{SbS}_{3},{ }^{[25]}$ which show a pronounced ionic conductivity in case of the copper and the silver compound. Halide free $\mathrm{Li}_{3} \mathrm{SbS}_{3}$ is obviously missing in this series of potentially ion conducting compounds. In addition,

\footnotetext{
* Prof. Dr. A. Pfitzner

Fax: +49-941-943-814551

E-Mail: arno.pfitzner@chemie.uni-regensburg.de

[a] Institut für Anorganische Chemie

Universität Regensburg

Universitätsstraße 31

93040 Regensburg, Germany
}

the question arises whether the green color of $\mathrm{Li}_{3} \mathrm{AsS}_{3}$ as described in the literature ${ }^{[3]}$ is intrinsic.

Herein we report on the synthesis, the structural characterization, and physical properties of $\mathrm{Li}_{3} \mathrm{SbS}_{3}$ and a new synthesis route for colorless $\mathrm{Li}_{3} \mathrm{AsS}_{3}{ }^{[4]}$

\section{Results and Discussion}

\section{Structure Determination}

The crystal structures of $\mathrm{Li}_{3} \mathrm{SbS}_{3}$ and of $\mathrm{Li}_{3} \mathrm{AsS}_{3}$ were determined by single-crystal X-ray diffraction. Crystallographic data are summarized in Table 1. Atomic coordinates and isotropic displacement parameters are collected in Table 2. Table 3 lists the anisotropic displacement parameters, and Table 4 shows selected interatomic distances and angles.

\section{Structure Description and Discussion}

$\mathrm{Li}_{3} \mathrm{SbS}_{3}$ and $\mathrm{Li}_{3} \mathrm{AsS}_{3}$ are isotypic and crystallize in the noncentrosymmetric orthorhombic space group Pna $2_{1}$. The basis of this structure type are isolated, trigonal pyramidal ( $\psi$-tetrahedral) $\left[\mathrm{PnS}_{3}\right]^{3-}$ units. These units are stacked in a kind of zigzag manner along $a$ (see Figure 1). The distances $d(\mathrm{Sb}-\mathrm{S})$ in the $\left[\mathrm{SbS}_{3}\right]^{3-}$ units are about $2.43 \AA$, and for $d(\mathrm{As}-\mathrm{S})$ about $2.26 \AA$ are observed. In both compounds no additional sulfur atoms are found in the range of $3.7 \AA$. The trigonal $P n \mathrm{~S}_{3}$ pyramids are interconnected by $\left[\mathrm{LiS}_{x}\right]$ polyhedra. Herein $\mathrm{Li} 2$ and Li3 have a distorted tetrahedral environment $\left[\mathrm{LiS}_{4}\right]$ with $d(\mathrm{Li} 2-\mathrm{S})=2.41(1)-2.49(1) \AA$ and $d(\mathrm{Li} 3-\mathrm{S})=2.42(1)-$ 
Table 1. Crystallographic data for the structure analysis of $\mathrm{Li}_{3} \mathrm{SbS}_{3}$ and $\mathrm{Li}_{3} \mathrm{AsS}_{3}$.

\begin{tabular}{|c|c|c|}
\hline & $\mathrm{Li}_{3} \mathrm{SbS}_{3}$ & $\mathrm{Li}_{3} \mathrm{AsS}_{3}$ \\
\hline Formula weight $/ \mathrm{g} \cdot \mathrm{mol}^{-1}$ & 238.75 & 191.92 \\
\hline Color & pale grey & colorless \\
\hline Crystal system & orthorhombic & orthorhombic \\
\hline Space group & $\operatorname{Pna2}_{1}$ (No. 33) & $\operatorname{Pna2}_{1}$ (No. 33) \\
\hline Lattice constants & $a=7.9671(5) \AA$ & $a=8.090(1) \AA$ \\
\hline \multirow[t]{2}{*}{ from single crystal data } & $b=6.7883(5) \AA$ & $b=6.658(1) \AA$ \\
\hline & $c=10.0912(8) \AA$ & $c=9.868(1) \AA$ \\
\hline Cell volume, $Z$ & $545.76(7) \AA^{3}, 4$ & $531.5(1) \AA^{3}, 4$ \\
\hline$\rho_{\text {calc }} / \mathrm{g} \cdot \mathrm{cm}^{-3}$ & 2.906 & 2.398 \\
\hline Diffractometer & Oxford Diffraction Gemini R & STOE IPDS, Mo- $K_{\alpha}, \lambda=0.71073 \AA$, \\
\hline & Ultra CCD, Mo- $K_{\alpha}, \lambda=0.71073 \AA$ & oriented graphite monochromator \\
\hline Absorption correction & Multi-scan ${ }^{[29]}$ & $\begin{array}{l}\text { Numerical, crystal description with } 12 \\
\text { faces, shape optimized with X-SHAPE }\end{array}$ \\
\hline Temperature $/{ }^{\circ} \mathrm{C}$ & 20 & 20 \\
\hline $2 \Theta$-range $/{ }^{\circ}$ & $7.2 \leq 2 \Theta \leq 56.7$ & $7.9 \leq 2 \Theta \leq 58.1$ \\
\hline \multirow[t]{3}{*}{$h k l$ range } & $-10 \leq h \leq 10$ & $-11 \leq h \leq 11$ \\
\hline & $-8 \leq k \leq 9$ & $-8 \leq k \leq 8$ \\
\hline & $-12 \leq l \leq 11$ & $-13 \leq l \leq 13$ \\
\hline No. of reflections, $R_{\mathrm{int}}$ & $3126,0.0356$ & $7095,0.0265$ \\
\hline No. of independent reflections & 1109 & 1354 \\
\hline No. of parameters & 63 & 64 \\
\hline Program & SHELX $97^{[30]}$ & SHELX 97 $7^{[30]}$ \\
\hline Final $R / w R\left(I>2 \sigma_{i}\right)$ & $0.0251,0.0484$ & $0.0130,0.0304$ \\
\hline Final $R / w R$ (all reflections) & $0.0337,0.0512$ & $0.0136,0.0306$ \\
\hline GooF & 1.036 & 1.043 \\
\hline Largest difference peak $\Delta p_{\max }$ & 0.754 & 0.311 \\
\hline and hole $\Delta p_{\min } / \mathrm{e} \cdot \AA^{-3}$ & -0.633 & -0.307 \\
\hline Extinction coefficient & - & $0.020(1)$ \\
\hline Flack parameter & $-0.07(8)$ & $0.002(6)$ \\
\hline
\end{tabular}

Table 2. Atomic coordinates and equivalent isotropic displacement parameters $U_{\text {eq }}$ for $\mathrm{Li}_{3} \mathrm{SbS}_{3}$ and $\mathrm{Li}_{3} \mathrm{AsS}_{3}$. All atoms are located on the Wyckoff position $4 a$.

\begin{tabular}{|c|c|c|c|c|}
\hline \multicolumn{5}{|c|}{$\mathrm{Li}_{3} \mathrm{SbS}_{3}$} \\
\hline Atom & $x$ & $y$ & $z$ & $U_{\mathrm{eq}}{ }^{\text {a) }}$ \\
\hline $\mathrm{Sb}$ & $0.7354(1)$ & $0.8951(1)$ & 0 & $0.016(1)$ \\
\hline $\mathrm{S} 1$ & $0.8373(4)$ & $0.6965(5)$ & $0.8174(4)$ & $0.018(1)$ \\
\hline S2 & $0.9633(2)$ & $0.1362(2)$ & $0.0083(5)$ & $0.018(1)$ \\
\hline S3 & $0.8207(4)$ & $0.7040(5)$ & $0.1927(4)$ & $0.019(1)$ \\
\hline Li1 & $0.054(2)$ & $0.960(2)$ & $0.776(2)$ & $0.038(3)$ \\
\hline $\mathrm{Li} 2$ & $0.912(1)$ & $0.343(2)$ & $0.818(1)$ & $0.023(3)$ \\
\hline Li3 & $0.761(2)$ & $0.375(2)$ & $0.114(1)$ & $0.032(3)$ \\
\hline \multicolumn{5}{|c|}{$\mathrm{Li}_{3} \mathrm{AsS}_{3}$} \\
\hline Atom & $x$ & $y$ & $z$ & $U_{\mathrm{eq}}{ }^{\mathrm{a})}$ \\
\hline As & $0.2467(1)$ & $0.0972(1)$ & 0 & $0.015(1)$ \\
\hline $\mathrm{S} 1$ & $0.1607(1)$ & $0.2909(1)$ & $0.1733(1)$ & $0.018(1)$ \\
\hline S2 & $0.0445(1)$ & $0.8601(1)$ & $0.9902(1)$ & $0.017(1)$ \\
\hline S3 & $0.1847(1)$ & $0.2803(1)$ & $0.8139(1)$ & $0.018(1)$ \\
\hline Li1 & $0.9343(4)$ & $0.0495(6)$ & $0.2184(4)$ & $0.031(1)$ \\
\hline $\mathrm{Li} 2$ & $0.0784(4)$ & $0.6462(5)$ & $0.1889(3)$ & $0.026(1)$ \\
\hline Li3 & $0.2513(4)$ & $0.6156(6)$ & $0.8890(4)$ & $0.029(1)$ \\
\hline
\end{tabular}

a) $U_{\text {eq }}$ is defined as one third of the trace of the orthogonalized $U_{\mathrm{ij}}$ tensor.

2.60(1) $\AA$ in $\mathrm{Li}_{3} \mathrm{SbS}_{3}$, and $d(\mathrm{Li} 2-\mathrm{S})=2.439(3)-2.508(3) \AA$ and $d(\mathrm{Li} 3-\mathrm{S})=2.413(4)-2.579(3) \AA$ in $\mathrm{Li}_{3} \mathrm{AsS}_{3}$, respectively. The $\left[\mathrm{Li}_{2} \mathrm{~S}_{4}\right]$ and $\left[\mathrm{Li}_{3} \mathrm{~S}_{4}\right]$ tetrahedra are connected by sharing one corner. In contrast Li1 has a distorted square-pyramidal coordination by sulfur in the case of $\mathrm{Li}_{3} \mathrm{SbS}_{3}(d(\mathrm{Li} 1-\mathrm{S})=2.52-$ $2.78 \AA$ ) and an even more distorted square pyramidal surrounding in case of $\mathrm{Li}_{3} \mathrm{AsS}_{3}$. In fact, $5+1$ coordination is found in both cases with the sixth sulfur atom in a distance of ca.
3.5 $\AA\left(\mathrm{Li}_{3} \mathrm{SbS}_{3}\right)$ and ca. $3.7 \AA\left(\mathrm{Li}_{3} \mathrm{AsS}_{3}\right)$. Similar to $\mathrm{Cu}_{3} \mathrm{SbS}_{3}{ }^{[14,15]}$ and $\mathrm{Cu}_{3} \mathrm{SbSe}_{3}{ }^{[18]}$ the structure of $\mathrm{Li}_{3} P n \mathrm{~S}_{3}$ can be derived from

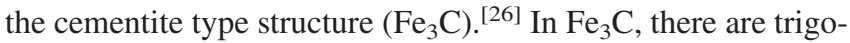
nal prisms $\mathrm{Fe}_{6}$ centered with carbon, and octahedral voids. In case of the title compounds iron is replaced by sulfur and carbon is replaced by the pnicogen atoms. However, the pnicogen atoms are located off center towards one triangular face of the prism. Thus, three short distances to sulfur are remaining 
Table 3. Anisotropic displacement parameters $U_{\mathrm{ij}}$ for $\mathrm{Li}_{3} \mathrm{SbS}_{3}$ and $\mathrm{Li}_{3} \mathrm{AsS}_{3}$.

\begin{tabular}{|c|c|c|c|c|c|c|}
\hline \multicolumn{7}{|c|}{$\mathrm{Li}_{3} \mathrm{SbS}_{3}$} \\
\hline Atom & $U_{11}$ & $U_{22}$ & $U_{33}$ & $U_{23}$ & $U_{13}$ & $U_{12}$ \\
\hline $\mathrm{Sb}$ & $0.017(1)$ & $0.016(1)$ & $0.015(1)$ & $0.000(1)$ & $-0.001(1)$ & $0.001(1)$ \\
\hline S1 & $0.022(1)$ & $0.016(2)$ & $0.015(1)$ & $-0.002(1)$ & $-0.001(1)$ & $0.000(1)$ \\
\hline S2 & $0.021(1)$ & $0.016(1)$ & $0.017(1)$ & $-0.001(2)$ & $0.001(2)$ & $-0.002(1)$ \\
\hline S3 & $0.024(1)$ & $0.015(2)$ & $0.019(2)$ & $0.001(1)$ & $-0.002(1)$ & $-0.002(1)$ \\
\hline Li1 & $0.025(7)$ & $0.035(8)$ & $0.05(1)$ & $0.007(7)$ & $0.001(6)$ & $0.004(6)$ \\
\hline Li2 & $0.024(6)$ & $0.026(6)$ & $0.019(7)$ & $-0.001(5)$ & $-0.008(5)$ & $0.002(5)$ \\
\hline Li3 & $0.040(8)$ & $0.020(6)$ & $0.036(9)$ & $-0.013(6)$ & $-0.001(6)$ & $0.004(6)$ \\
\hline \multicolumn{7}{|c|}{$\mathrm{Li}_{3} \mathrm{AsS}_{3}$} \\
\hline Atom & $U_{11}$ & $U_{22}$ & $U_{33}$ & $U_{23}$ & $U_{13}$ & $U_{12}$ \\
\hline As & $0.015(1)$ & $0.016(1)$ & $0.015(1)$ & $0.000(1)$ & $-0.001(1)$ & $0.001(1)$ \\
\hline S1 & $0.021(1)$ & $0.016(1)$ & $0.016(1)$ & $-0.002(1)$ & $0.000(1)$ & $0.000(1)$ \\
\hline S2 & $0.019(1)$ & $0.015(1)$ & $0.016(1)$ & $0.001(1)$ & $-0.002(1)$ & $-0.002(1)$ \\
\hline S3 & $0.023(1)$ & $0.017(1)$ & $0.015(1)$ & $-0.001(1)$ & $-0.001(1)$ & $-0.001(1)$ \\
\hline Li1 & $0.029(2)$ & $0.024(2)$ & $0.038(2)$ & 0.003(1) & $0.004(1)$ & $-0.001(1)$ \\
\hline Li2 & $0.027(1)$ & $0.025(2)$ & $0.027(1)$ & 0.004(1) & $0.001(1)$ & $0.005(1)$ \\
\hline Li3 & $0.031(2)$ & $0.023(2)$ & $0.032(2)$ & $-0.002(1)$ & $0.003(1)$ & $0.001(1)$ \\
\hline
\end{tabular}

(see Figure 2). Lithium atoms are located in non-occupied sites of this cementite-like arrangement. However, the monovalent cations can be located in different positions in this structural arrangement. For the copper containing compounds four possibilities to arrange copper on the faces of the $Q_{6}$ octahedra are observed: on two opposite faces, on two faces sharing one corner or one edge, or on four faces. ${ }^{[27]}$ In the lithium containing compounds Li2 and Li3 are located on two faces sharing one corner.

By contrast to the polymorphs of $\mathrm{Cu}_{3} \mathrm{SbS}_{3} \mathrm{Li1}$ is located within the $S_{6}$ octahedron (see Figure 3). However, it is shifted towards one corner of the surrounding octahedron. The distance to the sixth sulfur atom is $d(\mathrm{Li1}-\mathrm{S})=3.518 \AA\left(\mathrm{Li}_{3} \mathrm{SbS}_{3}\right)$ and $d(\mathrm{Li1}-\mathrm{S})=3.694 \AA\left(\mathrm{Li}_{3} \mathrm{AsS}_{3}\right)$, respectively. Thus, an effective coordination number of five results for Li1. Figure 4 shows the group-subgroup relationship of $\mathrm{Li}_{3} \mathrm{SbS}_{3}$ and $\mathrm{Li}_{3} \mathrm{AsS}_{3}$ with $\mathrm{Fe}_{3} \mathrm{C}$.

\section{DFT Calculations}

From DFT band structure calculations $\mathrm{Li}_{3} \mathrm{AsS}_{3}$ and $\mathrm{Li}_{3} \mathrm{SbS}_{3}$ are predicted as indirect semiconductors. To estimate the bandgap, electronic exchange and correlation were treated by pure DFT functionals (GGA) and additionally by increasingly applied hybrid functionals (see, for example references ${ }^{[32,33]}$ ). The first method tends to underestimate bandgaps of semiconductors (e.g. $\Delta E=0.7 \mathrm{eV}$ for $\mathrm{Si}$ ), while the latter over estimates them. For the title compounds all applied functionals give the same band structure characteristics shown for the GGA result on $\mathrm{Li}_{3} \mathrm{SbS}_{3}$ (Figure 5). From the difference of valence band maximum (VBM) and conduction band minimum $(\mathrm{CBM})$ a gap of $2.4 \mathrm{eV}$ is calculated $\left(\mathrm{Li}_{3} \mathrm{AsS}_{3}\right.$, GGA: $\left.2.5 \mathrm{eV}\right)$. A detailed analysis reveals that VBM and CBM are situated at different $k$ points, namely $Z$ and $T$. The predicted direct gap at $Z$ is $\Delta E>3.2 \mathrm{eV}$. Applying the well-known hybrid functionals B3PW, B3LYP, and PBE0 (see literature ${ }^{[32]}$ and references cited therein) the calculated gaps are 3.7 (3.9), 3.8 (4.0), and
4.0 (4.2) eV for $\mathrm{Li}_{3} \mathrm{SbS}_{3}\left(\mathrm{Li}_{3} \mathrm{AsS}_{3}\right)$, respectively. From these results one can conclude on optical gaps close to $3 \mathrm{eV}$ for the title compounds, which are in line with the observation of colorless crystals. The electronic gaps are due to the splitting of $\mathrm{Sb}-5 \mathrm{p}$ (As-4p) states due to bonding to $\mathrm{S}-3 \mathrm{p}$ as provided from the atomic site projected density of states (DOS, Figure 6). The $\mathrm{CBM}$ is mainly formed by antibonding $\mathrm{Sb}-5 \mathrm{p}$ states with minor contributions of S-3p. Concerning the valence band (VB) three major contributions can be distinguished due to bonding states from $\mathrm{Sb}-5 \mathrm{p}$ to $\mathrm{S}-3 \mathrm{p}$ ( -3 to $-4 \mathrm{eV}$ ) and nonbonding $\mathrm{S}-3 \mathrm{p}$. The top of the VB must be attributed to nonbonding Sb-5p states. Li-2s and 2p-orbitals contribute mainly to antibonding states above $5 \mathrm{eV}$.

\section{Impedance Spectroscopy}

Impedance spectroscopic measurements on cold pressed samples of $\mathrm{Li}_{3} \mathrm{SbS}_{3}$ were performed using gold as ion blocking electrode material. Nyquist plots show the typical behavior of an ionic conductor consisting of semicircles at high frequencies and diffusion arcs at low frequencies. Selected ionic conductivities are $1.6 \times 10^{-9} \Omega^{-1} \mathrm{~cm}^{-1}$ at $323 \mathrm{~K}$ and $5.4 \times 10^{-5} \Omega^{-1} \mathrm{~cm}^{-1}$ at $573 \mathrm{~K}$. The corresponding Arrhenius diagram provides an activation energy of $0.72 \mathrm{eV}$. Temperature dependent ionic conductivities of $\mathrm{Li}_{3} \mathrm{SbS}_{3}$ are shown in Figure 7. Comparable results have been already provided on this compound. ${ }^{[39]}$ Ionic transport measurements gave an $E_{A}$ of $0.40 \mathrm{eV}$ and the absorption edge was determined to $3.55 \mathrm{eV}$. This corresponds well to our results from impedance measurements $\left(E_{A}=0.72 \mathrm{eV}\right)$ and DFT calculations (optical gaps close to $3 \mathrm{eV})$.

\section{Raman Spectroscopy}

Raman measurements were performed on $\mathrm{Li}_{3} \mathrm{SbS}_{3}$ samples in sealed Duran glass capillaries. The spectra are dominated by strong stretching bands of the $\left[\mathrm{SbS}_{3}\right]^{3-}$ units. The $\mathrm{Sb}-\mathrm{S}$ 
Table 4. Selected interatomic distances $/ \AA$ and angles $/{ }^{\circ}$ for $\mathrm{Li}_{3} \mathrm{SbS}_{3}$ and $\mathrm{Li}_{3} \mathrm{AsS}_{3}$ at room temperature.

\begin{tabular}{|c|c|c|c|c|}
\hline \multicolumn{5}{|l|}{$\mathrm{Li}_{3} \mathrm{SbS}_{3}$} \\
\hline Sb1-S1 & & $2.423(4)$ & $\mathrm{S} 1-\mathrm{Sb} 1-\mathrm{S} 3$ & $102.55(6)$ \\
\hline $\mathrm{Sb} 1-\mathrm{S} 2$ & & $2.446(1)$ & S1-Sb1-S2 & $98.6(1)$ \\
\hline $\mathrm{Sb} 1-\mathrm{S} 3$ & & $2.434(4)$ & $\mathrm{S} 3-\mathrm{Sb} 1-\mathrm{S} 2$ & $97.0(1)$ \\
\hline Li1-S1 & $2 \times$ & $2.52(1)$ & S1-Li1-S1 & $106.6(5)$ \\
\hline Li1-S2 & & $2.74(2)$ & S1-Li1-S3 & 158.2(6) \\
\hline Li1-S2 & & $2.78(2)$ & S1-Li1-S3 & 94.6(4) \\
\hline \multirow{7}{*}{ Li1-S3 } & & $2.63(1)$ & S1-Li1-S2 & 89.1(4) \\
\hline & & & S1-Li1-S2 & 106.1(5) \\
\hline & & & S3-Li1-S2 & $89.7(4)$ \\
\hline & & & S1-Li1-S2 & $87.8(4)$ \\
\hline & & & S1-Li1-S2 & $96.3(5)$ \\
\hline & & & S3-Li1-S2 & $85.1(4)$ \\
\hline & & & S2-Li1-S2 & $157.4(5)$ \\
\hline Li2-S1 & & $2.47(1)$ & S2-Li2-S3 & 108.4(5) \\
\hline Li2-S2 & & 2.41(1) & S2-Li2-S1 & 127.3(5) \\
\hline Li2-S3 & & $2.44(1)$ & S3-Li2-S1 & $100.9(4)$ \\
\hline \multirow[t]{3}{*}{ Li2-S3 } & & $2.49(1)$ & S2-Li2-S3 & 100.7(4) \\
\hline & & & S3-Li2-S3 & 109.7(5) \\
\hline & & & S1-Li2-S3 & $109.2(5)$ \\
\hline Li3-S1 & & $2.51(2)$ & S3-Li3-S1 & $103.8(5)$ \\
\hline Li3-S2 & & $2.52(1)$ & S3-Li3-S2 & $127.4(6)$ \\
\hline Li3-S2 & & $2.60(1)$ & S1-Li3-S2 & $103.5(5)$ \\
\hline \multirow[t]{3}{*}{ Li3-S3 } & & $2.42(1)$ & S3-Li3-S2 & $110.0(5)$ \\
\hline & & & S1-Li3-S2 & 92.1(4) \\
\hline & & & S2-Li3-S2 & $113.0(5)$ \\
\hline
\end{tabular}

\begin{tabular}{llll}
\hline $\mathrm{Li}_{3} \mathrm{AsS}_{3}$ & & & \\
\hline As1-S1 & $2.252(1)$ & S3-As1-S2 & $100.38(2)$ \\
As1-S2 & $2.260(1)$ & S3-As1-S1 & $103.84(2)$ \\
As1-S3 & $2.275(1)$ & S2-As1-S1 & $101.99(2)$
\end{tabular}

\begin{tabular}{llll} 
Li1-S1 & $2.478(3)$ & S1-Li1-S1 & $110.3(1)$ \\
Li1-S1 & $2.495(3)$ & S1-Li1-S3 & $153.5(2)$ \\
Li1-S2 & $2.731(4)$ & S1-Li1-S3 & $95.6(1)$ \\
Li1-S2 & $2.754(4)$ & S1-Li1-S2 & $84.8(1)$ \\
Li1-S3 & $2.576(4)$ & S1-Li1-S2 & $109.8(1)$ \\
& & S3-Li1-S2 & $91.7(1)$ \\
& & S1-Li1-S2 & $89.3(1)$ \\
& & S1-Li1-S2 & $97.8(1)$ \\
& & S3-Li1-S2 & $81.6(1)$ \\
Li2-S1 & & S2-Li1-S2 & $152.1(1)$ \\
Li2-S2 & $2.462(4)$ & S2-Li2-S3 & $106.3(1)$ \\
Li2-S3 & $2.439(3)$ & S2-Li2-S1 & $122.8(1)$ \\
Li2-S3 & $2.449(3)$ & S3-Li2-S1 & $99.8(1)$ \\
& $2.508(3)$ & S2-Li2-S3 & $100.7(1)$ \\
& & S3-Li2-S3 & $110.2(1)$ \\
Li3-S1 & & S1-Li2-S3 & $116.6(1)$ \\
Li3-S2 & & & \\
Li3-S2 & $2.530(4)$ & S3-Li3-S1 & $103.4(2)$ \\
Li3-S3 & $2.539(4)$ & S3-Li3-S2 & $124.5(1)$ \\
& $2.579(3)$ & S1-Li3-S2 & $102.7(1)$ \\
& $2.413(4)$ & S3-Li3-S2 & $112.5(1)$ \\
& & S1-Li3-S2 & $92.2(1)$ \\
& & S2-Li3-S2 & $114.4(2)$ \\
\hline
\end{tabular}

stretching modes for these units are located between 330 and $360 \mathrm{~cm}^{-1} \cdot{ }^{[21,24,40-42]}$ For $\mathrm{Li}_{3} \mathrm{SbS}_{3}$, the $\left[\mathrm{SbS}_{3}\right]^{3-}$ units are isolated but surrounded by five additional sulfur atoms in the range of so called secondary bonds $(d(\mathrm{Sb}-\mathrm{S})=3.72-3.89 \AA)$.

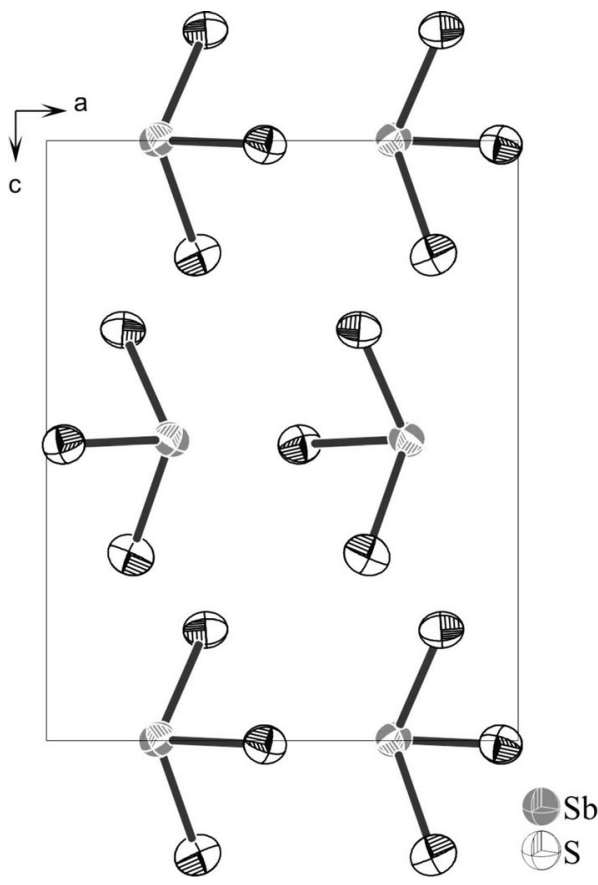

Figure 1. Arrangement of the $\left[\mathrm{SbS}_{3}\right]^{3-}$ units along the $b$ axis. Lithium ions are omitted for clarity.

Due to additional $\mathrm{Sb}-\mathrm{S}$ bonds, the bands are red-shifted. ${ }^{[21,40]}$ For the title compound, the vibrations are observed at 333, 317 , and $301 \mathrm{~cm}^{-1}$. The Raman spectrum is shown in Figure 8. Compared to the Raman spectra of $\mathrm{Cu}_{3} \mathrm{SbS}_{3},{ }^{[21]}(\mathrm{CuI})_{2}$ $\mathrm{Cu}_{3} \mathrm{SbS}_{3},{ }^{[21]}$ and $(\mathrm{AgI})_{2} \mathrm{Ag}_{3} \mathrm{SbS}_{3},{ }^{[24]}$ lowering the symmetry of the $\left[\mathrm{SbS}_{3}\right]^{3-}$ unit from $C_{\mathrm{s}}$ to $C_{1}$ leads to a splitting of the modes.

\section{Conclusions}

$\mathrm{Li}_{3} \mathrm{SbS}_{3}$ is structurally characterized as a new member of the $M_{3}^{\mathrm{I}} P n Q_{3}$ chalcogenometalate family. It crystallizes orthorhombically in the space group $P n a 2_{1}$ (no. 33). $\mathrm{Li}_{3} \mathrm{SbS}_{3}$ is isotypic to $\mathrm{Li}_{3} \mathrm{AsS}_{3}$, which was prepared by a new synthesis route. Herein, LiI serves as a flux and is not incorporated in the structure of $\mathrm{Li}_{3} \mathrm{AsS}_{3}$. $\mathrm{Li}_{3} \mathrm{AsS}_{3}$ crystallizes as colorless rods and not as green crystals as published earlier. ${ }^{[3]}$ This fits with results from electronic structure calculations that predict bandgaps of approximately $3 \mathrm{eV}$ for both compounds. The gaps are determined by splitting of bonding and antibonding states from bonding of Sb-5p (As-4p) to S-3p. Impedance spectroscopic measurements show high ionic conductivity for $\mathrm{Li}_{3} \mathrm{SbS}_{3}$. The conductivity is in the range of $1.6 \times 10^{-9} \Omega^{-1} \mathrm{~cm}^{-1}$ at $323 \mathrm{~K}$ and $5.4 \times 10^{-5} \Omega^{-1} \mathrm{~cm}^{-1}$ at $573 \mathrm{~K}$. The corresponding Arrhenius plot provides an activation energy of $0.72 \mathrm{eV}$. Raman spectra of $\mathrm{Li}_{3} \mathrm{SbS}_{3}$ are dominated by strong stretching modes of the $\left[\mathrm{SbS}_{3}\right]^{3-}$ units at 333,317 , and $301 \mathrm{~cm}^{-1}$, which indicates a strong influence of the sulfur atoms in a so-called non-bonding distance to antimony.

\section{Experimental Section}

Synthesis: $\mathrm{Li}_{3} \mathrm{SbS}_{3}$ was prepared by reaction of $\mathrm{Li}_{2} \mathrm{~S}(99.9 \%$, Alfa Aesar) and $\mathrm{Sb}_{2} \mathrm{~S}_{3}$ (Merck) in the ratio $3: 1, \mathrm{Li}_{3} \mathrm{AsS}_{3}$ of $\mathrm{LiI}$ (anhydrous, 

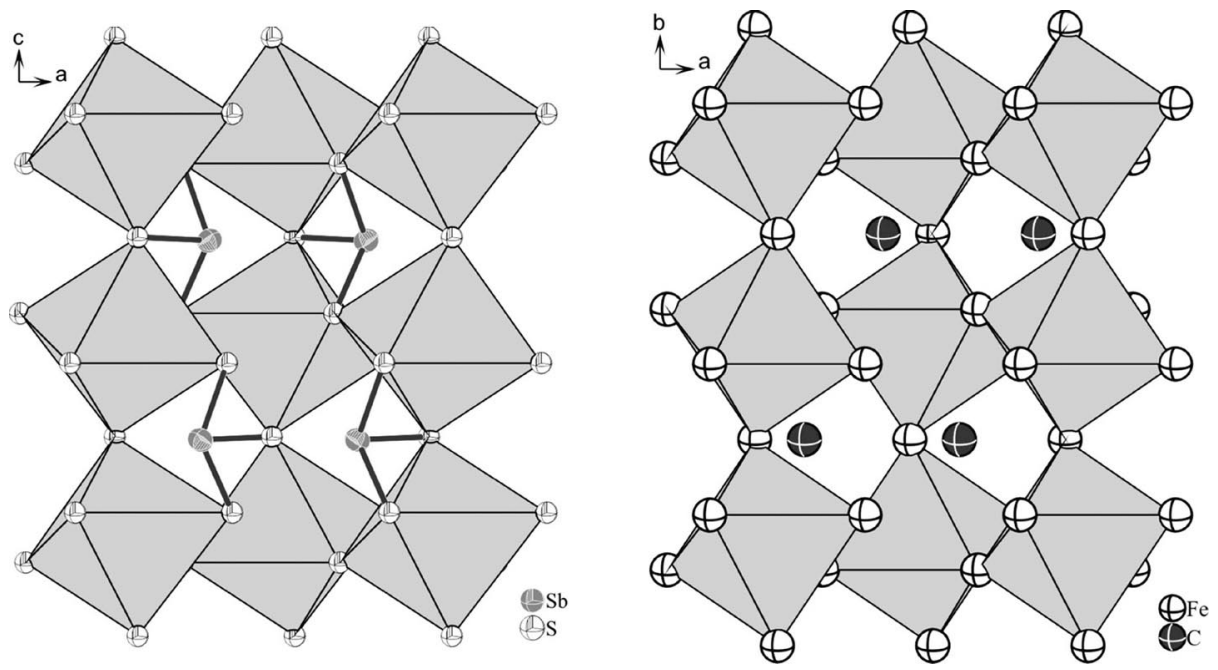

Figure 2. Section of the crystal structures of $\mathrm{Li}_{3} \mathrm{SbS}_{3}$ and $\mathrm{Fe}_{3} \mathrm{C}$ showing the structural similarities between both compounds. Lithium ions are omitted for clarity.
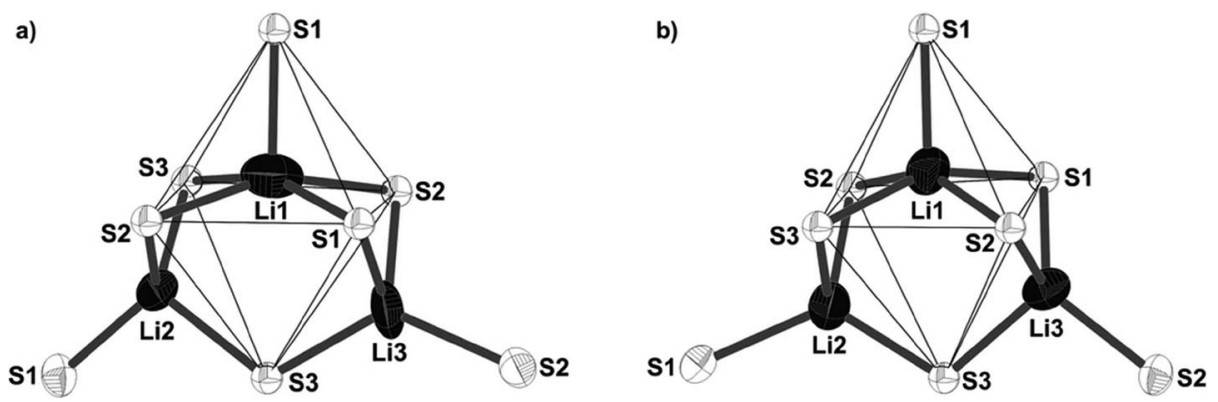

Figure 3. Occupation of the $\mathrm{S}_{6}$-octahedra in $\mathrm{Li}_{3} \mathrm{SbS}_{3}$ (a) and $\mathrm{Li}_{3} \mathrm{AsS}_{3}$ (b). Li2 and $\mathrm{Li} 3$ are located on two faces sharing one corner. Both are coordinated by four sulfur atoms in a distorted tetrahedral manner. Li1 is located in the $\mathrm{S}_{6}$-octahedron, but significantly shifted to one corner. Thus, it is regarded as only five-coordinate.

Merck), Li (99.999\%, Merck), As (99.999\%, Alfa Aesar), and S (99.9995\%, Merck) in the ratio 2:3:1:3. All preparations were performed in a glove box in an atmosphere of argon. The reagents were filled in graphitized, evacuated silica ampoules. For $\mathrm{Li}_{3} \mathrm{SbS}_{3}$, the starting materials were annealed for 3 weeks at $500{ }^{\circ} \mathrm{C}$, for $\mathrm{Li}_{3} \mathrm{AsS}_{3}$, the materials were slowly heated up to $200{ }^{\circ} \mathrm{C}$, then faster to $450{ }^{\circ} \mathrm{C}$, and were further annealed for 1 week at $350{ }^{\circ} \mathrm{C}$. Pale grey crystals of $\mathrm{Li}_{3} \mathrm{SbS}_{3}$ and colorless crystals of $\mathrm{Li}_{3} \mathrm{AsS}_{3}$, suitable for single-crystal $\mathrm{X}$-ray structure determination, could be separated from the reaction product. Both products are air and moisture sensitive.

X-ray Crystallography: For the structure determination at room temperature single crystals were filled in a closed glass capillary and mounted on an Oxford Diffraction Gemini R Ultra CCD providing monochromatic Mo- $K_{\alpha}$ radiation $(\lambda=0.71073 \AA)$ in the case of $\mathrm{Li}_{3} \mathrm{SbS}_{3}$. Absorption was corrected by multi-scans. ${ }^{[29]}$ For $\mathrm{Li}_{3} \mathrm{AsS}_{3}$ the crystals were mounted on an IPDS (Stoe) single crystal diffractometer providing monochromatic Mo- $K_{\alpha}$ radiation $(\lambda=0.71073 \AA)$. Absorption was corrected numerically after an optimization of the description of the crystal shape with the X-SHAPE routine. ${ }^{[31]}$ Crystallographic data are collected in Table 1. The crystal structures were solved by Direct Methods (SIR92). ${ }^{[36]}$ Li positions were located from difference Fourier maps. All atoms were refined by using anisotropic displacement parameters. An extinction parameter was included in the last refinement stages for $\mathrm{Li}_{3} \mathrm{AsS}_{3}$, in case of $\mathrm{Li}_{3} \mathrm{SbS}_{3}$ it was equal to zero within the e.s.d. and therefore not refined. The $z$-coordinate of $\mathrm{Sb}$ and
As, respectively, were fixed during the refinement in order to make the positional parameters as comparable as possible. The Flack-parameter is equal to zero in both cases, indicating that no inversion twinning is observed.

DFT Methods: The electronic structures were calculated with the codes CRYSTAL09 ${ }^{[33]}$ and FPLO9. ${ }^{[34]}$ The first one additionally allows for the use of GGA ( $\mathrm{PBE}^{[35]}$ ) and hybrid functionals (B3PW, B3LYP, PBE0, see references ${ }^{[32,33]}$ ). The band structure calculation results were confirmed from all electron and valence basis sets, as well as from PBE calculations with the full-potential local orbital-code FPLO9 ${ }^{\left[{ }^{34]}\right.}$ For this code extended all electron basis sets are optimized at each cycle of the SCF routine. The k-points mesh was converged to $12 \times 12 \times 12$ shrinking factors.

Impedance Spectroscopy: Impedance spectroscopic investigations were performed in the frequency range $1 \mathrm{~Hz}$ to $1 \mathrm{MHz}$ and the temperature range $323 \mathrm{~K}$ to $573 \mathrm{~K}$ (IM6d, Zahner Elektrik). The powdered samples of $\mathrm{Li}_{3} \mathrm{SbS}_{3}$ were cold pressed into pellets with $6000 \mathrm{~kg} \cdot \mathrm{cm}^{-2}$, resulting in a density of $>90 \%$ of the calculated density. They were contacted in a spring loaded cell between gold electrodes. Details of the experimental setup are given elsewhere. ${ }^{[37]}$

Raman Spectroscopy: Raman measurements were carried out with a Varian Fourier transform Raman module coupled to a Varian FTS 7000 e spectrometer equipped with a Nd:YAG laser (excitation wave- 


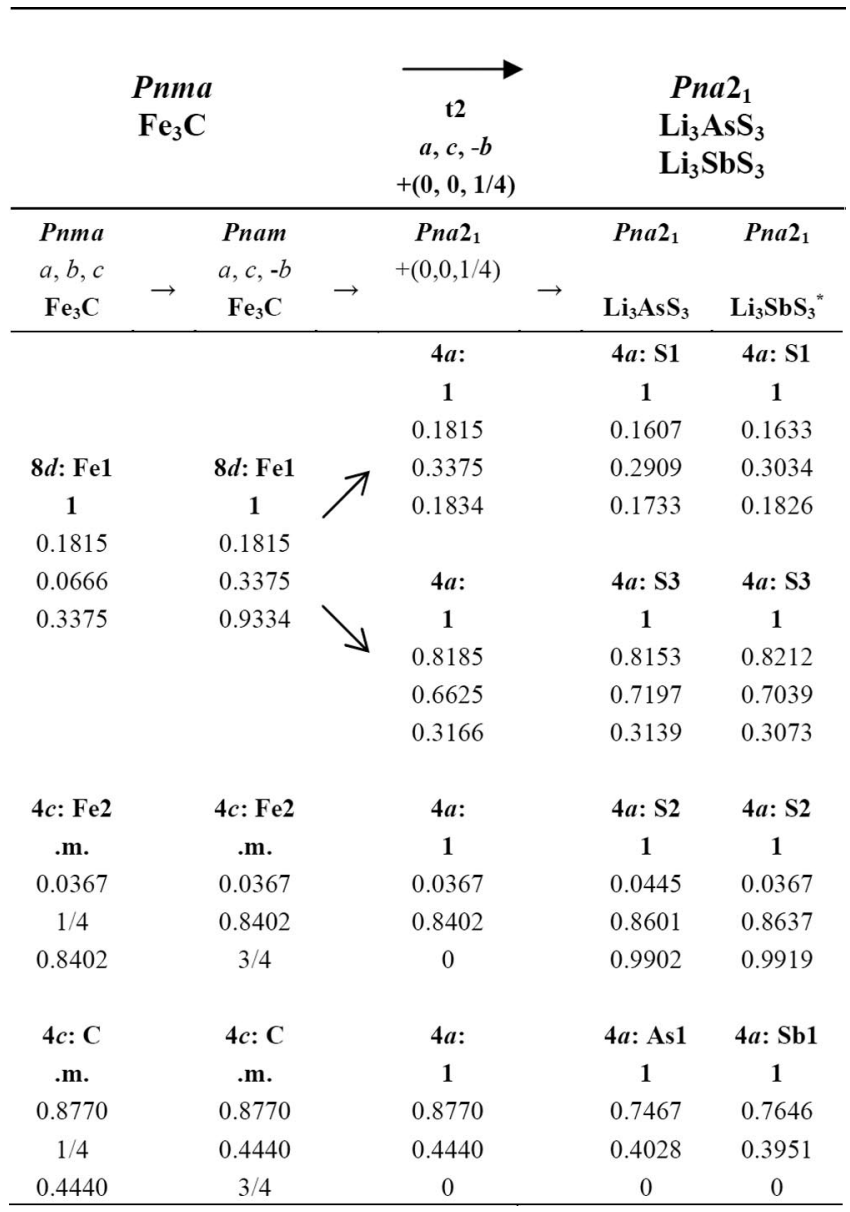

Figure 4. Symmetry relations between $\mathrm{Li}_{3} \mathrm{SbS}_{3} / \mathrm{Li}_{3} \mathrm{AsS}_{3}$ and $\mathrm{Fe}_{3} \mathrm{C}$ (Bärnighausen-Stammbaum). ${ }^{[28]}$ Upon the transition from Pnam to $P n a 2_{1}$ the $8 d$ site splits into two $4 a$ sites. *Structural data for $\mathrm{Li}_{3} \mathrm{SbS}_{3}$ are inverted for comparison.

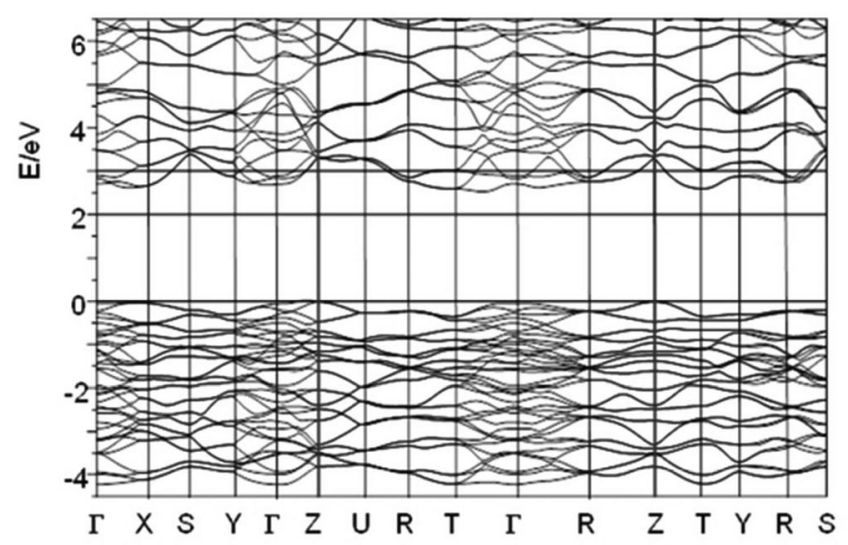

Figure 5. Electronic band structure (GGA), lines are pointed out as guide for the eyes at $k=Z$ and $E=3 \mathrm{eV}$.

length $\lambda=1064 \mathrm{~nm}$ ) and a liquid nitrogen cooled germanium detector. The powdered samples of $\mathrm{Li}_{3} \mathrm{SbS}_{3}$ were sealed in Duran glass capillaries. The resolution was $2 \mathrm{~cm}^{-1}$ and the spectrum was processed with the Varian Resolutions Pro software. ${ }^{[38]}$

Further details of the crystal structure investigations may be obtained from the Fachinformationszentrum Karlsruhe, 76344 Eggenstein-Leo-

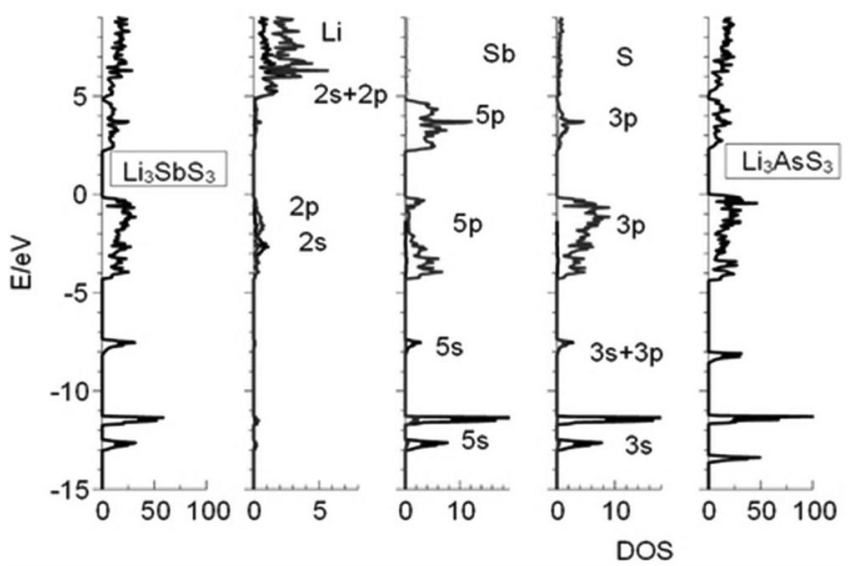

Figure 6. Electronic density of states and atomic site projections for $\mathrm{Li}_{3} \mathrm{SbS}_{3}$, and total DOS for $\mathrm{Li}_{3} \mathrm{AsS}_{3}$.

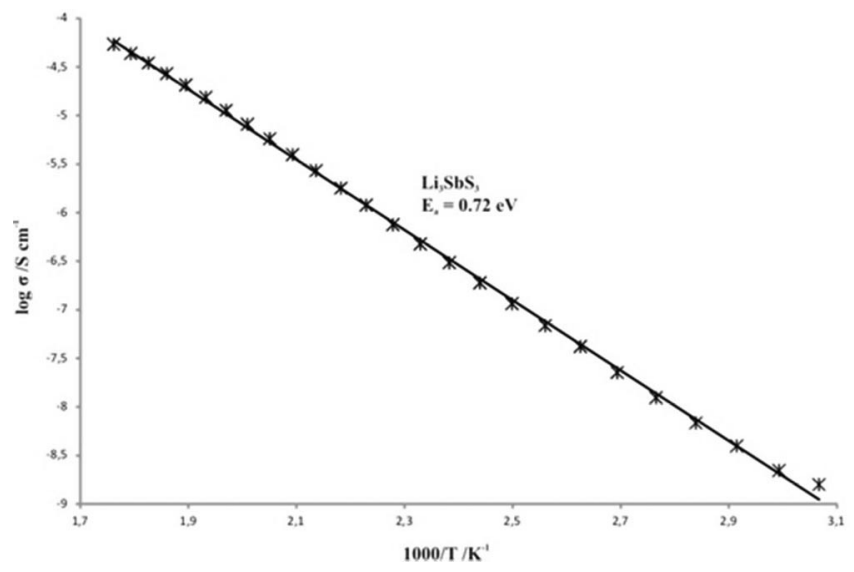

Figure 7. Temperature dependence of the ionic conductivity of $\mathrm{Li}_{3} \mathrm{SbS}_{3}$.

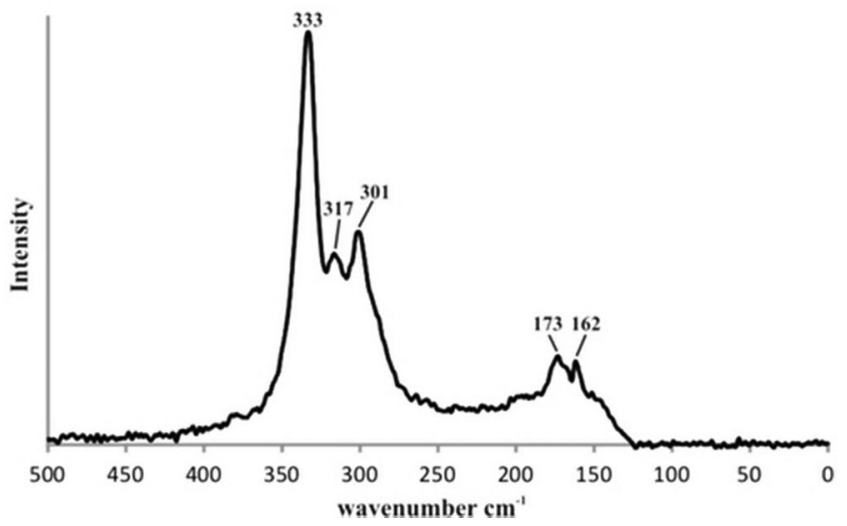

Figure 8. Raman spectrum of $\mathrm{Li}_{3} \mathrm{SbS}_{3}$. It is dominated by the stretching modes of the $\left[\mathrm{SbS}_{3}\right]^{3-}$ units.

poldshafen, Germany (Fax: +49-7247-808-666; E-Mail: crysdata@fizkarlsruhe.de, http://www.fiz-karlsruhe.de/request for deposited data.html) on quoting the depository numbers CSD-424834 $\left(\mathrm{Li}_{3} \mathrm{SbS}_{3}\right)$ and CSD-424835 $\left(\mathrm{Li}_{3} \mathrm{AsS}_{3}\right)$. 


\section{Acknowledgements}

We thank Dr. M. Bodensteiner for collecting single-crystal X-ray diffraction data of $\mathrm{Li}_{3} \mathrm{SbS}_{3}$.

\section{References}

[1] H. Sommer, R. Hoppe, Z. Anorg. Allg. Chem. 1977, 430, 199.

[2] W. Bronger, A. Donike, D. Schmitz, Z. Anorg. Allg. Chem. 1999, $625,435$.

[3] D.-Y. Seung, P. Gravereau, L. Trut, A. Levasseur, Acta Crystallogr. Sect. C 1998, 54, 900.

[4] C. Preitschaft, Dissertation, Regensburg 2004.

[5] M. Palazzi, Acta Crystallogr., Sect. B 1976, 32, 3175.

[6] W. Bronger, A. Donike, D. Schmitz, Z. Anorg. Allg. Chem. 1998, $624,553$.

[7] W. Bronger, A. Donike, D. Schmitz, Z. Anorg. Allg. Chem. 1996, $622,1003$.

[8] W. Bronger, A. Donike, D. Schmitz, Z. Anorg. Allg. Chem. 1997, 623,1715

[9] D. Harker, J. Chem. Phys. 1936, 4, 381.

[10] P. Engel, W. Nowacki, Acta Crystallogr., Sect. B 1968, 24, 77.

[11] K. Sakai, T. Koide, T. Matsumoto, Acta Crystallogr., Sect. B 1978, 34, 3326.

[12] K. Kihara, T. Matsumoto, Z. Kristallogr. 1986, 177, 211.

[13] M. G. Kanatzidis, J.-H. Chou, J. Solid State Chem. 1996, 127, 186.

[14] A. Pfitzner, Z. Anorg. Allg. Chem. 1994, 620, 1992.

[15] A. Pfitzner, Z. Kristallogr. 1998, 213, 228.

[16] S. Karup-Møller, E. Makovicky, Am. Mineral. 1974, 59, 889.

[17] B. J. Skinner, F. D. Luce, E. Makovicky, Econ. Geol. 1972, 67, 924.

[18] A. Pfitzner, Z. Anorg. Allg. Chem. 1995, 621, 685.

[19] E. J. Skoug, J. D. Cain, D. T. Morelli, Appl. Phys. Lett. 2010, 96, 181905.

[20] M. Kirkham, P. Majsztrik, E. Skoug, D. Morelli, H. Wang, W. D. Porter, E. A. Payzant, E. Lara-Curzio, J. Mater. Res. 2011, 26, 2001.

[21] A. Pfitzner, Chem. Eur. J. 1997, 3, 2032.
[22] T. J. Bastow, H. J. Whitfield, J. Solid State Chem. 1981, 40, 203.

[23] T. Nilges, Dissertation, Siegen 2000.

[24] T. Nilges, S. Reiser, J. H. Hong, E. Gaudin, A. Pfitzner, Phys. Chem. Chem. Phys. 2002, 4, 5888.

[25] A. Pfitzner, C. Preitschaft, F. Rau, Z. Anorg. Allg. Chem. 2004, 630, 75.

[26] E. J. Fasiska, G. A. Jeffrey, Acta Crystallogr. 1965, 19, 463.

[27] A. Pfitzner, Habilitationsschrift, Siegen 2000.

[28] H. Bärnighausen, MATCH 1980, 9, 139.

[29] SCALE3 ABSPACK, CrysAlis RED software, Version 171.35.21; Oxford Diffraction Ltd: Oxford, UK, 2006.

[30] G. M. Sheldrick, SHELX 97 Programs for Solution and Refinement of Crystal Structures, University of Göttingen, Germany, 1997.

[31] X-SHAPE, STOE, Darmstadt, Germany, 1996.

[32] a) X. Zheng, A. J. Cohen, P. Mori-Sánchez, X. Hu, W. Yang, Phys. Rev. Lett. 2011, 107, 0264031; b) S. Tomic, B. Montanari, N. M. Harrison, Phys. E 2008, 40, 2125.

[33] R. Dovesi, V. R. Saunders, C. Roetti, R. Orlando, C. M. ZicovichWilson, F. Pascale, B. Civalleri, K. Doll, N. M. Harrison, I. J. Bush, P. D'Arco, M. Llunell, CRYSTAL09, User's Manual. University of Torino, Torino, 2009.

[34] K. Köpernik, H. Eschrig, Phys. Rev. B 1999, 59, 1743.

[35] J. P. Perdew, K. Burke, M. Ernzerhof, Phys. Rev. Lett. 1996, 77, 3865 .

[36] A. Altomare, G. Cascarano, C. Giacovazzo, A. Guagliardi, J. Appl. Crystallogr. 1993, 26, 343.

[37] E. Freudenthaler, A. Pfitzner, Solid State Ionics 1997, 101-103, 1053.

[38] Resolutions Pro Software, Molecular Spectroscopy Solutions, Varian Inc., Version 4.1.0.101, 2006.

[39] J. Olivier-Fourcade, M. Maurin, E. Philippot, Solid State Ionics 1983, 9,10, 135.

[40] A. Pfitzner, D. Kurowski, Z. Kristallogr. 2000, 215, 373.

[41] V. Spetzler, C. Näther, W. Bensch, Inorg. Chem. 2005, 44, 5805.

[42] R. Kiebach, R. Warratz, C. Näther, W. Bensch, Z. Anorg. Allg. Chem. 2009, 635, 988.

Received: June 14, 2012

Published Online: September 7, 2012 